\title{
Parental Influence on Student Educational Expectations: Results from the 2012 Qatar Education Study
}

\author{
Abdel Latif Sellami ${ }^{1}$ \\ ${ }^{1}$ The Social \& Economic Survey Research Institute (SESRI), Qatar University, Qatar. \\ Correspondence: Abdel Latif Sellami, The Social \& Economic Survey Research Institute (SESRI), Qatar University, \\ The State of Qatar. E-mail: asellami@qu.edu.qa
}

Received: July 8, 2019

Accepted: July 24, 2019

Online Published: July 25, 2019

doi:10.5430/ijhe.v8n4p189

URL: https://doi.org/10.5430/ijhe.v8n4p189

\begin{abstract}
This study investigated factors that are likely to influence students' educational expectations in the State of Qatar, concentrating on selected parental factors. Drawing on recent work in the field, the study examined the intersection of student demographic and socio-economic attributes along with contextual factors, on student educational expectations. The study uses student and parent data from a nation-wide survey of preparatory and secondary schools, the 2012 Qatar Education Study. The results showed students' gender and grade level positively affect their reported educational expectations, with females and those in higher grade levels more likely to report higher expectations. While student reports of parental involvement were not significant, parent reports were marginally significant. The paper concludes with some recommendations for further study and research.
\end{abstract}

Keywords: student educational expectations, parental involvement, Qatar

\section{Introduction}

Educational aspirations and expectations are measures commonly used in the literature to capture educational goals and ambitions (Schmitt-Wilson \& Faas, 2016). Although the direction of much research in education has highlighted associations between both educational aspirations and educational expectations (Beal \& Crockett, 2010; Boxer et al., 2011), the two concepts have historically been treated as if they were inseparable. As a general rule, educational expectations have been distinguished from aspirations in that they entail what a person expects to achieve, rather than what they desire, hope or wish to achieve (Khattab, 2014, 2015; Reynolds \& Pemberton, 2001). This study aims to investigate the impact of parents' involvement in the schooling of their children on the educational expectations of the children.

The bulk of studies that examine student educational expectations have been carried out in the West, especially the US and Western European countries (DeWitt, Archer, \& Osborne, 2014; Feliciano \& Rumbaut, 2005; Lowman \& Elliott, 2010; Reynolds \& Pemberton, 2001; Vryonides \& Gouvias, 2012). However, not enough is known about the educational expectations of young adolescents in other parts of the world. This is especially the case with countries such as Qatar (Al-Thani, Abdelmoneim, Daoud, Cherif \& Moukarzel, 2014; Elsharnouby, 2015; Gauntlett, 2006). Existing research has demonstrated that while the majority of high school students, for example, aspire to further their education after graduating from high school, the number of students who actually succeed in completing a college degree is rather low (Kirst \& Venezia, 2004; Price \& Tovar, 2014; Pruett, 2015; Schneider \& Yin, 2012).

Overall, different factors have been identified in the literature as predictors of student educational expectations. Chief among these is the important and critical role of parental involvement in their child(ren)'s education (Ceja, 2006; Cheng \& Starks, 2002; Ellison, Wohn \& Greenhow, 2014; McCarron \& Inkelas, 2006; Trusty, 1998; Trusty \& Harris, 1999). Given education is not solely confined to the school setting as it also occurs in the student's home and the larger community, this study seeks to explore parental influence as a potential predictor of the educational expectations of their children in Qatar. Empirical research is needed to examine different aspects of parental influence on the educational prospects of their children at different stages of schooling in Qatar and the region.

The study examined the factors associated with student educational expectations in Qatar, concentrating on the influence of parents within the context of student variables (gender and grade level). While several educational scholars have looked at the way parental attributes influence student expectations (McCarron \& Inkelas, 2006; Sosu, 2014; Vryonides \& Gouvias, 2012), few have examined the degree to which research on this topic also informs our 
understanding of educational expectations in the Arab world and the Arabian Gulf in particular. The educational marketplace and local context provide an incentive structure that may influence student expectations beyond the parent-child dynamic.

The study aimed to extend the previous literature in an attempt to fill this gap in the literature and expand current understanding of how parent involvement in school affects the educational aspirations and expectations of their children. Specifically, the study sought answers to three specific research questions:

a. What are the educational expectations of Qatari students?

b. What are the key student characteristics that are associated with higher educational expectations?

c. Does parent involvement in their child's education lead to higher educational expectations?

\section{Review of Literature}

Students' educational expectations have been associated with both short-term and long-term educational goals and aspirations (Khattab, 2014; 2015). While educational aspirations refer to how much education a person would like to achieve (Alexander, Bozick \& Entwisle, 2008; Reynolds \& Pemberton, 2001; Khattab, 2014), educational expectations are defined as how much education a student thinks he or she will attain, (Beal \& Crockett, 2010; Khattab, 2015; Ou \& Reynolds, 2008; Trusty, 2000). While previous research has looked at aspirations (Uwah, McMahon, \& Furlow, 2008; Wahl \& Blackhurst, 2000), this paper examines educational expectations because of how the question was phrased in the Qatar Education Study (QES) survey and also because it is a more accurate reflection of what the students had in mind when asked about it: students were asked how far they thought they would get in their studies (expectations), rather than how far they would like to (aspirations).

Past research shows that primary school students who do not aspire to a university education may make different choices in secondary school, opting for less rigorous courses and spending less time concentrating on school work, than students who plan to obtain a Baccalaureate or graduate degree (Croll, 2008; DeWitt \& Archer, 2015; De Witt, Archer \& Osborne, 2014; Sammons, Toth \& Sylva, 2016). Students' early educational expectations have also been associated with their eventual entry into a career in a STEM field (Tyson, Lee, Borman \& Hanson, 2007; Sadler, Sonnert, Hazari \& Tai, 2012). Miller and Solberg (2012) found that students who planned to obtain a Baccalaureate degree or higher while in high school were substantially more likely to eventually be a STEM professional than those who did not plan on graduating from college.

Parents can influence their children's educational experiences and outcomes in a variety of ways. At the most basic level, the children of college-educated parents have higher levels of achievement than children whose parents did not graduate from college (Davis-Kean, 2005; Davis-Kean \& Sexton, 2009; Eivers \& Creaven, 2013; Garg, Melanson \& Levin, 2007). The effective participation of parents in matters related to the education of their children has been shown to have a significant impact on their academic performance at school (Dearing, McCartney \& Taylor, 2001; Jeynes, 2010; Karbach, Gottschling, Spengler, Hegewald \& Spinath, 2013; Wilder, 2014). Using data based on a meta-analysis of research regarding parental participation in their children's education, Hill and Tyson (2009) found a significant positive relationship between students' academic achievement and parents' involvement in their education. Similar results were concluded by Scott and Mallinckrodt (2005) who argued that parents who value and support their child's educational level have a significant and positive impact on their children's education.

Parental involvement with their children's education can also influence their children's educational outcomes (Hay, Wright, Watson, Allen, Beswick \& Cranston, 2016; Paik, 2004; Wang, 2004). However, there is no common definition or agreement as to the meaning of parent involvement. Parent involvement can range from such activities as attendance at school events to membership in parent-teacher organizations to discussions with their children about school to assistance with homework (Barnard, 2004; Duckworth, 2008; Desforges \& Abouchaar, 2003; Epstein \& Sanders, 2009; Flouri, 2006; Hill \& Tyson, 2009; Jeynes, 2010). For the purposes of this study, this research explores the effect of parents' help with homework, as a specific type of parental involvement, on students' educational expectations. This will help in ascertaining whether parental involvement in homework is a predictor of their child(ren)'s expectations to pursue post-secondary education and eventually attend a higher education institution.

Research on parental involvement in children's education shows that checking homework is an important aspect of their participation in their children's school learning at home (Hao \& Bonstead-Bruns, 1998). Homework is a significant component of students' learning experience (Hoover-Dempsey, Battiato, Walker, Reed, DeJong, \& Jones, 2001; Patall, Cooper, \& Robinson, 2008); it enhances their academic achievement and fosters their engagement with 
learning (Cooper \& Valentine, 2001; Doctoroff \& Arnold, 2017). It also serves as a crucial point of interface between the school and the home and enhances home-school collaboration (Epstein, 2010).

The impact of gender gaps in educational expectations are well documented (Blackhurst \& Auger, 2008; King, 2010; Wells, Seifert \& Saunders, 2013). For example, gender has been shown to be a critical determinant in students' decisions related to their educational and occupational paths (Andres \& Adamuti-Trache, 2007; Bradley, 2000; Kleinjans, 2010). In a study of post-secondary 9th and 10th grade students, Davis and Pearce (2007) found a positive relationship between gender and student expectation to go to college, especially for girls. Similar results were concluded by Clark, Thompson and Vialle (2008), Feliciano and Rumbaut (2005), Reynolds and Burge (2008), Wells, Seifert, Padgett, Park and Umbach (2011), and Wood, Kaplan and McLoyd (2007).

Another line of research has examined more closely the connections between student educational expectations and their level of education (Chang, Min, Shi, Kenny, \& Loyalka, 2016; Englund, Luckner, Whaley, \& Egeland, 2004; Trusty, 2002; Trusty, Plata, \& Salazar, 2003). Students' educational expectations are shown to increase as they progress in their education (Entwisle, Alexander, \& Olson, 2005; Goyette, 2008; Lowman \& Elliott, 2010; Schmitt-Wilson \& Faas, 2016). Thus, students in higher stages of education have been found to report they expect to earn a higher degree (Jacob \& Wilder, 2010; McDaniel, 2009; Reynolds \& Burge, 2008; Turley, Santos, \& Ceja, 2007).

\section{The Case of Qatar}

The abundant hydrocarbon resources of Qatar have provided the nation with incredible wealth and its citizens with economic security for at least the last decade. Qatari citizens are the primary beneficiaries of the state's revenue from oil and gas production and receive many government-subsidized services including free education, universal health care, and low-interest or no-interest loans (Staz, Eide, \& Martorell, 2007). They are also a minority subgroup in their own country, with both white-collar and unskilled migrant laborers filling the bulk of private sector employment.

The wealth of Qatar has also created cultural expectations in conflict with educational attainment. Qatar has a large public sector, and the jobs within this sector - including the military and the police - are among the highest paid and least demanding within the nation, while at the same time requiring minimal educational attainment. Understanding student perspectives and engagement with learning and schooling in Qatar helps to comprehend why 75\% of Qataris are employed in government sectors (Golkowska, 2014; Staz, Eide, \& Martorell, 2007).

Many studies note citizens in Qatar, and throughout the GCC countries for that matter, have a penchant for public sector jobs for life because they are "less demanding in terms of attendance (shorter working hours and longer vacations), effort, skills and performance at work." (Harry, 2007, p. 137). These jobs also provide high salaries, better employment conditions, greater job security (Al-Waqfi \& Forstenlechner, 2010; Forstenlechner \& Mellahi, 2011; Forstenlechner \& Rutledge, 2011).

The nation's youth have traditionally exhibited relatively low educational expectations (Khalifa, Nasser, Ikhlef, Walker, \& Amali, 2016; Stasz, Eide, \& Martorell, 2007). Here, it should be noted that Qatari boys seem to be less motivated compared to girls and have less positive attitudes toward learning and schooling (Lee, 2016). In terms of enrolment in higher education, Qatar displays a clear gender gap, with female participation ahead of that of males (Berrebi, Martorell \& Tanner, 2009). Evidence indicates Qatari women outnumber men in the different post-secondary programs on offer in the country for two main reasons.

Firstly, males tend to enter the job market and secure a well-paid government job directly upon the completion of their high school education; secondly, those who decide to pursue education often study abroad, an opportunity that is not immediately available to their female counterparts (Frieze, Hazzan, Blum \& Dias, 2006; Staz, Eide \& Martorell, 2007). Education occupies a prominent position in the agenda of Qatar's leadership. Recognizing that the hydrocarbon resources will not last indefinitely, the State of Qatar has detailed goals to move from a reliance on its gas and oil wealth to a knowledge based economy by 2030 (GSDP, 2008).

Consistent with these goals, the country has invested considerable resources to modernize its entire educational system and has initiated new educational policies and programs intended to enhance the quality of education in Qatar (GSDP, 2012). This stems from the recognition of the critical role education can play as a vehicle for the country's transition into a knowledge society, as is identified in the QNV 2030 and the National Development Strategy (QNDS). As part of this focus on educational improvement, all key stakeholders - school administrators, teachers, and parents - are held responsible for the success of students within the country. A key goal of the education reform has been to increase parental involvement with the education of their children (GSDP, 2011). 
Research has consistently shown that in addition to effective pedagogies, quality curricula and competent teachers, parents also have a central role to play in a child's education (Anderson \& Minke, 2007; James, 2008). Qatar National Development Strategy identifies parental involvement in K-12 education as one of the goals identified for the Qatar National Vision (QNV) 2030 and calls for parents' increased participation in their children's education (GSDP, 2011).

The government of Qatar has invested heavily in developing an appropriate physical infrastructure and the human capital needed to enhance the education sector (Stasz, Eide \& Martorell, 2007). As is articulated in the Education and Training Sector Strategy (ETSS) 2011, which falls under the Qatar National Strategy 2011-2016, "Qatar will need to continue to make substantial investments in education and training, which will produce well rounded and engaged citizens who are prepared to support the nation's industry, science and medicine" (The Ministry of Education \& Higher Education, 2016, p. 7), thus making the study especially salient in light of the national priorities the government of Qatar has outlined.

\section{Methodology}

\subsection{Participants}

Participants included in this study are Qatari students $(n=730)$ and a parent or guardian $(n=497)$. The students are from two preparatory grades $(21.7 \%$ th grade, $n=156 ; 27.1 \%$ 9th grade, $n=192)$ and two secondary grades $(21.5 \%$ 11 th grade, $n=161 ; 29.7 \% 12$ th grade $n=221)$. The average age of students by grade is: 8 th grade (13), 9th grade (14), 11th grade (16), and 12th grade (17). The students are 52.3\% male $(n=368)$ and $47.7 \%$ female $(n=362)$ and their race-ethnicity is $100 \%$ Qatari. The parents are $57.9 \%$ male and $42.1 \%$ female, and have an average age of 41 .

\subsection{Procedure}

This study used data collected from students and parents from the 2012 Qatar Education Study (The Social \& Economic Survey Research Institute, 2012). The school system in Qatar is organized into the following categories: 1) independent; 2) international; 3) community; and 4) Arabic private. The majority of Qatari students attend government-financed independent schools, which are all single-gender schools. In our study, the distribution of Qatari students across school type is as follows: 1) $93 \%$ independent schools $(n=742)$; 2$) 4 \%$ international schools $(n=28), 3) 4 \%$ Arabic private schools $(n=31)$ and 4$)<1 \%$ Community schools $(n=1)$.

The Qatar Education Study (QES) is based on a nationally representative two-stage probability school sample of Qatari students. The sampling frame for the survey comes from a comprehensive list of public and private schools provided by the Qatar Supreme Council of Education (replaced by the Ministry of Education and Higher Education in early 2016 as part of a government reorganization). The first stage sample was a proportionate sample of schools based on school size, school type (i.e. independent, international, community, and Arabic private), gender (boy, girl, or coed) and grade (8th, 9th, 11th, or 12th). In stage two, one class from each grade in a school was randomly selected and all students in the class were included in the survey. Students were given a printed parent questionnaire to give to one of their parents at home.

Upon receiving approval from the Internal Review Board, official letters requesting permission to conduct the study were sent to the schools. Parents/guardians and students were informed in advance about the aim of the study, that participation in the survey was voluntary and that all of their answers would be confidential. No questionnaires were distributed until consent for the study was obtained.

Forty-three schools were initially sampled, with four schools refusing to participate, resulting in a response rate of $90.7 \%$ at the school level. Classrooms were randomly selected in 39 schools and all students in selected classrooms fully participated in the survey. However, no information is available regarding the actual class sizes to calculate a response rate at the classroom level. This design resulted in 1,848 students (both Qatari and non-Qatari) and 1,472 parents. The response rate of parents was 79. 6\%. For purposes of this article only data from the Qatari national students is used $(n=730)$ as the intent is to provide information that may be useful for Qatar's future educational policy and planning. The maximum sampling error was calculated at $+/-2$ percentage points for the student survey and $+/-2.7$ percentage points for the parent survey.

The mode of data collection was self-administered paper-and-pencil questionnaire. The students completed the questionnaires in their classroom. Trained interviewers were present in the classroom to clarify any confusion or concerns of the students and to observe the quality of the responses. Students recruited for the school survey were asked to have one of their parents complete a paper-and-pencil survey. The students brought the parent questionnaire to their home and returned it to the school once completed where a fieldworker collected them. 


\subsection{Measures}

The measures described below were used in four logistic regression models to predict student educational expectations: (1) Model 1 including student report of parental help with homework; (2) Model 2 including a parent report of parental help with homework; (3) Model 3 including an interaction between the student report of parental help with homework and gender; and (4) Model 4 including an interaction between the parent report of parental help with homework and gender.

\subsubsection{Dependent Variable: Educational Expectations}

Educational expectations is a composite measure meant to gauge a student's reported future educational plans and his or her confidence in reaching those goals. Three questions from the QES were combined to form a dichotomous variable indicating when a student reported high levels of confidence that he or she would be continuing on to postsecondary education. Students were first asked their plans for proceeding with education after finishing high school. Next, they assessed how confident they were in reaching their educational goals and their likelihood of proceeding to college after finishing secondary school. For students to be coded as having expectations for postsecondary education they must have responded that they planned to join a Baccalaureate program, planned to graduate from college, or planned to finish postgraduate studies. In addition, the student must have responded that he or she felt somewhat or very confident in their ability to graduate from secondary school, and that he or she felt that continuing on to college after high school was somewhat or very likely.

\subsubsection{Independent Variables.}

The study examined Qatari students' plans to pursue postsecondary education based on a number of factors.

\subsubsection{Gender.}

To test whether there are gender differences in educational expectations in Qatar, student-reported gender is included in the model as a dichotomous variable with 1 indicating that the student is a female and 0 a male.

\subsubsection{Grade Level.}

To test whether educational expectations are affected by the grade of the student, a dummy variable was included to indicate whether a student is in preparatory school (grades 8 or 9) or secondary school (grade 11 or 12). Preparatory school students are coded as 0 and secondary school students are coded as 1 .

\subsubsection{Parent's Education Level.}

In the QES parent survey, the responding parent was asked to give their highest level of educational attainment and that of their spouse. Both answers where collapsed into a dichotomous variable indicating that the parent had attained at least a Baccalaureate degree or that the parent had received less than a Baccalaureate. An indicator variable was created for each student coded as 1 when one or both parents had attained at least a Baccalaureate, and 0 if neither parent attained at least a Baccalaureate.

\subsubsection{Homework Help - Student and Parent Reports.}

Both students and parents were asked to report how often parents checked their child's homework. This study created separate dichotomous measures of student and parent reports of parental help with homework, to allow us to consider the differential effects of student versus parent reports of help with homework in competing models. In both the student and parent measure, 1 indicates that the parents or students reported that parents checked their child's homework at least once a week; 0 was used to see if parents or students stated that parents never checked their child's homework.

\subsubsection{Homework/Gender Interaction.}

As parent interest in a student's work may be affected by the gender of the child, an interaction term was included to capture the relationship between the student's gender and reported homework help. This interaction is calculated with the student-reported homework help for the student models and parent-reported homework help for the parent models.

In addition to the above variables, this study included fixed effects in the models to capture differences based on the type of school that the student attends. Fixed effects are meant to capture unmeasured heterogeneity in the model (Allison, 2009; Clark, Crawford, Steele \& Vignoles, 2010). Fixed effects models are particularly useful in cases where researchers are interested in the effect of individual characteristics on an outcome variable and in which at the same time, the mechanisms by which students enroll in specific schools are poorly understood and lack measurement specificity. In this case, this study hypothesized that the type of school the student attends - International, 
Independent, Arabic private, or Community - may affect the amount of emphasis on postsecondary education a child receives. In addition, the system choice may indicate parental preferences for postsecondary attainment by their children.

Table 1 shows the percentage of students planning on obtaining a Baccalaureate degree or higher for each independent variable included in the models. The majority of students in every category express expectations of higher degree attainment.

Table 1. Descriptive Statistics

\begin{tabular}{ccc}
\hline & $\begin{array}{c}\text { Bachelor's } \\
\text { or higher }\end{array}$ & $N$ \\
\hline All Qatari students & $72.0 \%$ & 730 \\
Females & 79.3 & 362 \\
Males & 66.8 & 368 \\
Grade 8-9 & 67.1 & 348 \\
Grade 11-12 & 78.5 & 382 \\
Parents with high school or less & 70.4 & 449 \\
Parent with B.A. or higher & 77.6 & 281 \\
Students report parents help with homework & 74.4 & 551 \\
Students do not report parents help with homework & 69.9 & 179 \\
Parents report they help with homework & 74.3 & 420 \\
Parents do not report they help with homework & 87.9 & 66 \\
\hline
\end{tabular}

\section{Results}

\section{Logistic Regression with Fixed Effects}

The QES includes both student and parent reported answers relating to the level of parental involvement in their child's academic life. It was expected that parental involvement would affect students' educational expectations and that parents and students might differ in their perceptions of the level of parental involvement. Therefore, this study included results from a set of models using student-reported data and a second set of models using parent-reported data.

This study presents results of logistic regression models with fixed effects for both student and parent reported responses estimating the probability of a student having highly confident expectation for earning a postsecondary degree. The study starts with a base model that examines the likelihood of students reporting plans for postsecondary education. This model includes all of the covariates discussed above, but does not include the interaction term. Since the QES measured both student and parent perceptions of involvement, two models were run: once with student-reported results and again with the parent-reported results.

The base model suggests that student educational expectations are significantly related to the gender of the student and their grade level. Both characteristics positively affect a student's reported expectations for postsecondary education, meaning that female students and students in higher grade levels are more likely to report plans to obtain a Baccalaureate degree or higher. While student reports of parents helping with homework fails to reach statistical significance, parent reported help is marginally significant. However, the results are not in the expected direction as they suggest that a parent helping with homework reduces the likelihood that students will report postsecondary educational expectations. Overall, the results of the baseline model explain only a small amount of the variation in student educational expectations.

The interaction term for student gender and parent's help with homework is unchanged from the previous model and the results are similar to the baseline model. In the student-reported version, gender and grade level are positively and significantly associated with student educational expectations. Gender drops from significance in the parent-reported model and switches directions, but parent reported homework help remains significant in the negative direction. The interaction term is not statistically significant in either model. 


\section{Discussion}

This paper explores the factors that bear upon students' educational expectations in Qatar and looks at the intersection of students' gender and grade level. In so doing, it focuses on the parent-related variables, such as parent education, student reports of help they receive from their parents with homework, and parent reports of help they give to students with homework. The results of these logistic regressions confirm our predictions in regard to the effect of gender and grade level on student educational expectations.

Female students are more likely to report plans for postsecondary education, perhaps because they view education as more important to their independence and success than their male counterparts. Indeed, gender gaps in educational expectations are well-documented and the results from the present study are consistent with findings from other research investigating the impact of gender on educational expectations (Blackhurst \& Auger, 2008; Wells, Seifert \& Saunders, 2013).

The results also show that students' education level is a predictor of educational expectations which increase as students progress in their education. For students in higher grade levels are more likely to express expectations for and confidence in achieving postsecondary degrees. This could be partly due to the educational level of students' parents and students' career aspirations. These results, which might reflect greater connection with education in the upper grade levels, or a better understanding of the importance of education, corroborate findings of previous research (Chang, Min, Shi, Kenny \& Loyalka, 2016; Englund, Luckner, Whaley \& Egeland, 2004).

The negative direction of the coefficient for parent-reported homework help could have a number of important implications. Parents may be more watchful of students that are uninterested in school and therefore unlikely to do their homework without supervision. These same students may be more likely to report low levels of educational expectations. Moreover, parents may also be more likely to check struggling students' homework, and those students may express less confidence in achieving postsecondary educational goals.

The disparity between the negative and statistically significant parent-reported results and the positive and not significant student-reported results could be due to a number of factors, including a failure of either students or parents to honestly report how often parents check homework or measurement error from imprecise survey questions. The models explain only a small percent of the variance in student educational expectations, suggesting that other unmeasured variables, including unobserved differences within the schools have greater effects on students' perceptions of higher education and confidence in their own achievement.

\section{Conclusion}

This study sought to shed light on key determinants of students' educational expectations in Qatar, concentrating specifically on important parental factors. Drawing on insights from existing scholarship, the study examined the relationship between students' demographic, socio-economic and contextual factors, and their educational expectations. In particular, the attributes of gender and grade level were found to be positively associated with the educational expectations reported by students.

Exploring students' educational expectations provides a Middle Eastern perspective that may help in deciphering the social, economic and cultural influences that are rapidly changing the face of education and employment opportunities for local Qatari nationals. Moreover, understanding the answers to the study's questions sheds light on how parent involvement matters (or not) for long-term education outcomes in Qatar and informs future studies of a similar nature in the region or countries with similar student populations.

\subsection{Limitations}

One limitation of the current study is its sole reliance on questionnaires in collecting data.

Complementing the quantitative results with qualitative data would not only help to explore students' educational expectations in greater depth; it would also provide an alternative perspective and thus yield results that are more robust. Because questionnaires cannot adequately capture nuances in respondents' views and opinions, using student/parent in-depth or focus group interviews will illuminate the study's findings further. Moreover, given education is a manifestation of the social, cultural and political systems that are prevalent in a society, it is difficult to compare the current research with other studies conducted outside the Middle East and North Africa region. It then follows that the social and cultural norms and values of a society shape its education system (Barbour, Barbour \& Scully, 2008). 


\subsection{Future Research}

Previous research has shown parental involvement to be an important factor that influences the educational expectations of children. While this study sought to unveil the impact of parents' involvement in their children's education on students' educational expectations, future studies should look at how educational expectations change over time vis-à-vis a longitudinal study. Further research is needed to better understand variation in developmental trajectories of these expectations from adolescence and even earlier to adulthood. Little is known about the trajectories of Qatari students' educational expectations across different lower and upper stages of education. There is also need for an additional examination of the extent to which these findings generalize to other societies with extremely heterogeneous and predominantly immigrant student populations.

\section{Acknowledgements}

This work was supported by Dr. Linda Kimmel, Dr. Anna Cotter, Jill Wittrock, and the Social and Economic Survey Research Institute, Qatar University. The author would like to thank all the students and parents who took part in the 2015 Qatar Education Study. The author would also like to thank Dr. Abdoulaye Diop, Dr. Elmogeira Elawad, and Mr. Isam Mohamed Abdelhameed in giving so generously of their time at various stages of the data collection and entry.

\section{References}

Alexander, K., Bozick, R. \& Entwisle, D. (2008). Warming up, cooling out, or holding steady? Persistence and change in educational expectations after high school. Sociology of Education, 81(4), 371-396. https://dx.doi.org/10.1177/003804070808100403

Allison, P. D. (2009). Fixed effects regression models. Thousand Oaks, CA: SAGE Publications, Inc. https://doi.org/10.4135/9781412993869

Al-Misnad, S. A. (2015). The dearth of Qatari men in higher education: Reasons and implications. Washington, DC: Middle Easter

Institute. http://www.mei.edu/content/dearth-qatari-men-higher-education-reasons-and-implications

Al-Thani, S. J., Abdelmoneim, A., Daoud, K., Cherif, A. \& Moukarzel, D. (2014). A perspective on student learning outcome assessment at Qatar University. Quality in Higher Education, 20(3), 255-271. https://dx.doi.org/10.1080/13538322.2014.964079

Al-Waqfi, M. \& Forstenlechner, I. (2010). Stereotyping of citizens in an expatriate-dominated labour market: Implications for workforce localisation policy. Employee Relations, 32(4), 364-381. https://dx.doi.org/10.1108/01425451011051596

Anderson, K. J. \& Minke, K. M. (2007). Parent involvement in education: Toward an understanding of parents' decision making. The Journal of Educational Research, 100(5), 311-323. DOI: 10.3200/JOER.100.5.311-323

Andres, L. \& Adamuti-Trache, M. (2007). You've come a long way, baby? Persistent gender inequality in university enrolment and completion in Canada, 1979-2004. Canadian Public Policy,33(1), 93-116. https://dx.doi.org/10.3138/cpp.v33.1.093

Barbour, C., Barbour, N. \& Scully, P. A. (2008). Families, schools, and communities: Building partnerships for educating children. Upper Saddle River, N.J: Pearson/Merrill Prentice Hall.

Barnard, W. M. (2004). Parent involvement in elementary school and educational attainment. Children \& Youth Services Review, 26(1), 39-62. https://dx.doi.org/10.1016/j.childyouth.2003.11.002

Beal, S. J. \& Crockett, L. J. (2010). Adolescents' occupational and educational aspirations and expectations: Links to high school activities and adult educational attainment. Developmental Psychology, 46(1), 258-265. https://dx.doi.org/10.1037/a0017416

Berrebi, C., Martorell, F. \& Tanner, J. C. (2009). Qatar's labor markets at a crucial crossroad. The Middle East Journal, 63(3), 421-442. https://dx.doi.org/10.3751/63.3.14

Blackhurst, A. E. \& Auger, R. W. (2008). Precursors to the gender gap in college enrollment: Children's aspirations and expectations for their futures. Professional School Counseling, 11(3), 149-158. https://dx.doi.org/10.5330/PSC.n.2010-11.149 
Boxer, P., Goldstein, S. E., DeLorenzo, T., Savoy, S. \& Mercado, I. (2011). Educational aspiration-expectation discrepancies: Relation to socioeconomic and academic risk-related factors. Journal of Adolescence, 34(4), 609-617. https://doi.org/10.1016/j.adolescence.2010.10.002

Bradley, K. (2000). The incorporation of women into higher education: Paradoxical outcomes? Sociology of Education, 73(1), 1-18. https://dx.doi.org/10.2307/2673196

Ceja, M. (2006). Understanding the role of parents and siblings as information sources in the college choice process of Chicana students. Journal of College Student Development, 47(1), 87-104. https://dx.doi.org/10.1353/csd.2006.0003

Chang, F., Min, W., Shi, Y., Kenny, K. \& Loyalka, P. (2016). Educational expectations and dropout behavior among junior high students in rural China. China \& World Economy, 24(3), 67-85. https://dx.doi.org/10.1111/cwe.12159

Cheng, S. \& Starks, B. (2002). Racial differences in the effects of significant others on students' educational expectations. Sociology of Education, 75(4), 306-327. https://dx.doi.org/10.2307/3090281

Clark, M., Thompson, P. \& Vialle, W. (2008). Examining the gender gap in educational outcomes in public education: Involving preservice school counsellors and teachers in cross-cultural and interdisciplinary research. International Journal for the Advancement of Counselling, 30(1), 52-66. https://dx.doi.org/10.1007/s10447-007-9044-7

Clark, P., Crawford, C., Steele, F. \& Vignoles, A. (2010). The choice between fixed and random effects models: Some considerations for educational research. Institute for the Study of Labor. IZA Discussion Paper No. 5287.

Cooper, H. C. \& Valentine, J. C. (2001). Using research to answer practical questions about homework. Educational Psychologist, 36(3), 143-153. http://dx.doi.org/10.1207/S15326985EP3603_1

Croll, P. (2008). Occupational choice, socio-economic status and educational attainment: A study of the occupational choices and destinations of young people in the British Household Panel Survey. Research Papers in Education, 23(3), 243-268. https://dx.doi.org/10.1080/02671520701755424

Davis, S. N. \& Pearce, L. D. (2007). Adolescents' work-family gender ideologies and educational expectations. Sociological Perspectives, 50(2), 249-271. https://dx.doi.org/10.1525/sop.2007.50.2.249

Davis-Kean, P. E. (2005). The influence of parent education and family income on child achievement: The indirect role of parental expectations and the home environment. Journal of Family Psychology, 19, 294-304. https://dx.doi.org/10.1037/0893-3200.19.2.294

Davis-Kean, P. E. \& Sexton, H. R. (2009). Race differences in parental influences on child achievement: Multiple pathways to success. Merrill-Palmer Quarterly, 55(3), 285-318. https://dx.doi.org/10.1353/mpq.0.0023

Dearing, E., McCartney, K. \& Taylor, B. A. (2001). Change in family income matters more for children with less. Child Development, 72, 1779-1793. https://dx.doi.org/10.1111/1467-8624.00378

Desforges, C. \& Abouchaar, A. (2003). The impact of parental involvement, parental support and family education on pupil achievement and adjustment: A literature review. DfES Research Report 433. 11.

DeWitt, J. \& Archer, L. (2015). Who aspires to a science career? A comparison of survey responses from primary and secondary school students. International Journal of Science Education, 37(13), 2170-2192. https://dx.doi.org/10.1080/09500693.2015.1071899

DeWitt, J., Archer, L. \& Osborne, J. (2014). Science-related aspirations across the primary-secondary divide: Evidence from two surveys in England. International Journal of Science Education, 36(10), 1609-1629. https://dx.doi.org/10.1080/09500693.2013.871659

Doctoroff, G. L. \& Arnold, D. H. (2017). Doing homework together: The relation between parenting strategies, child engagement, and achievement. Journal of Applied Developmental Psychology, 48, 103-113. https://dx.doi.org/10.1016/j.appdev.2017.01.001

Duckworth, K. (2008). The influence of context on attainment in primary school: Interactions between children, family and school contexts. Centre for Research on the Wider Benefits of Learning, Institute of Education, University of London. http://eprints.ioe.ac.uk/5964/1/Duckworth2008theinfluence.pdf 
Eivers, E. \& Creaven, A. M. (2013). Home-school interaction. In E. Eivers \& A. Clerkin (Eds.), National schools, international contexts: Beyond the PIRLS and TIMSS test results, 105-128. Dublin: Educational Research Centre.

Ellison, N. B., Wohn, D. Y. \& Greenhow, C. M. (2014). Adolescents' visions of their future careers, educational plans, and life pathways: The role of bridging and bonding social capital experiences. Journal of Social and Personal Relationships, 31(4), 516-534. https://dx.doi.org/10.1177/0265407514523546

Elsharnouby, T. H. (2015). Student co-creation behavior in higher education: The role of satisfaction with the university experience. Journal of Marketing for Higher Education, 25(2), 238-262. https://dx.doi.org/10.1080/08841241.2015.1059919

Englund, M., Luckner, A., Whaley, G. \& Egeland, B. (2004). Children's achievement in early elementary school: Longitudinal effects of parental involvement, expectations, and quality of assistance. Journal of Educational Psychology, 96(4), 723-730. https://dx.doi.org/10.1037/0022-0663.96.4.723

Entwisle, D. R., Alexander, K. L. \& Olson, L. S. (2005). First grade and educational attainment by age 22: A new story. American Journal of Sociology, 110(5), 1458-1502. https://dx.doi.org/10.1086/428444

Epstein, J. L. (2010). School, family, and community partnerships: Caring for the children we share. Phi Delta Kappan, 92(3), 81-96. https://dx.doi.org/10.1177/003172171009200326

Epstein, J. L. \& Sanders, M. G. (2009). School, family, and community partnerships: Your handbook for action (3 ${ }^{\text {rd }}$ ed.). Thousand Oaks, CA: Corwin Press.

Feliciano, C. \& Rumbaut, R. G. (2005). Gendered paths: Educational and occupational expectations and outcomes among adult children of immigrants. Ethnic and Racial Studies, 28(6), 1087-1118. https://dx.doi.org/10.1080/01419870500224406

Flouri, E. (2006). Parental interest in children's education, children's self-esteem and locus of control, and later educational attainment: Twenty-six year follow-up of the 1970 British birth cohort. British Journal of Educational Psychology, 76, 41-55. https://dx.doi.org/10.1348/000709905X52508

Forstenlechner, I. \& Mellahi, K. (2011). Gaining legitimacy through hiring local workforce at a premium: The case of MNEs in the United Arab Emirates. Journal of World Business, 46(4), 455-461. https://doi.org/10.1016/j.jwb.2010.10.006

Forstenlechner, I. \& Rutledge, E. J. (2011). The GCC's "demographic imbalance": Perceptions, realities and policy options. Middle East Policy, 18(4), 25-43. https://dx.doi.org/10.1111/j.1475-4967.2011.00508.x

Frieze, C., Hazzan, O., Blum, L. \& Dias, M. B. (2006). Culture and environment as determinants of women's participation in computing: Revealing the women-CS fit. In ACM SIGCSE Bulletin, 38(1), 22-26. https://dx.doi.org/10.1145/1121341.112135

Garg, R., Melanson, S. \& Levin, E. (2007). Educational aspirations of male and female adolescents from single-parent and two biological parent families: A comparison of influential factors. Journal of Youth \& Adolescence, 36, 1010-1023. http://dx.doi.org/10.1007/s10964-006-9137-3

Gauntlett, K. (2006). The challenge of understanding the academic expectations of Gulf sponsored students: Traditional student aspirations versus modern graduate attributes. Paper presented at the Annual ISANA International Education Association Conference, Sandy Bay, Australia.

General Secretariat for Development Planning (GSDP). (2008). Qatar national vision 2030. : http://www.gsdp.gov.qa/portal/page/portal/gsdp_en/qatar_national_vision/qnv_2030_document on 08/04/2015

General Secretariat for Development Planning (GSDP). (2011). Qatar national development strategy 2011-2016 (NDS). : http://www.gsdp.gov.qa/gsdp_vision/docs/NDS_EN.pdf

General Secretariat for Development Planning (GSDP). (2012). Qatar's third national human development report: the capacities of Qatari youth. http://www.youthpolicy.org/library/wp-content/uploads/library/2012_Qatar_Human_Development_Report_Eng .pdf

Golkowska, K. U. (2014). Arab women in the Gulf and the narrative of change: The case of Qatar. International Studies: Interdisciplinary Political and Cultural Journal, 16(1), 51-64. http://dx.doi.org/10.2478/ipcj-2014-0004 
Goyette, K. A. (2008). College for some to college for all: Social background, occupational expectations, and educational expectations over time. Social Science Research, 37(2), 461-484. http://dx.doi.org/10.1016/j.ssresearch.2008.02.002

Hao, L. \& Bonstead-Bruns, M. (1998). Parent-child differences in educational expectations and the academic achievement of immigrant and native students. Sociology of Education, 175-198. http://dx.doi.org/10.2307/2673201

Harry, W. (2007). Employment creation and localization: The crucial human resource issues for the GCC. The International Journal of Human Resource Management, 18(1), 132-146. http://dx.doi.org/10.1080/09585190601068508

Hay, I., Wright, S., Watson, J., Allen, J., Beswick, K. \& Cranston, N. (2016). Parent-child connectedness for schooling and students' performance and aspirations: An exploratory investigation. International Journal of Educational Research, 77, 50-61. http://dx.doi.org/10.1016/j.ijer.2016.02.004

Hill, N. E. \& Tyson, D. F. (2009). Parental involvement in middle school: A meta-analytic assessment of the strategies that promote achievement. Developmental Psychology, 45(3), 740. http://dx.doi.org/10.1037/a0015362

Hoover-Dempsey, K. V., Battiato, A. C., Walker, J. M., Reed, R. P., DeJong, J. M. \& Jones, K. P. (2001). Parental involvement in $\quad$ homework. Educational $\quad$ Psychologist, 36(3), http://dx.doi.org/10.1207/S15326985EP3603_5

Jacob, B. A. \& Wilder, T. (2010). Educational expectations and attainment (No. w15683). National Bureau of Economic Research. http://www.nber.org/papers/w15683.pdf https://doi.org/10.3386/w15683

James, M. L. (2008). Parental involvement in their child's education. (Unpublished doctoral dissertation). Capella University. Minneapolis, Minnesota, USA.

Jeynes, W. (2010). Parental involvement and academic success. London: Routledge. https://doi.org/10.4324/9780203843444

Karbach, J., Gottschling, J., Spengler, M., Hegewald, K. \& Spinath, F. M. (2013). Parental involvement and general cognitive ability as predictors of domain-specific academic achievement in early adolescence. Learning and Instruction, 23, 43-51. http://dx.doi.org/10.1016/j.learninstruc.2012.09.004

Khalifa, B., Nasser, R., Ikhlef, A., Walker, J. S. \& Amali, S. (2016). A qualitative study of student perceptions, beliefs, outlook and context in Qatar: Persistence in higher education. Paper presented at the Qatar Foundation Annual Research Conference, Doha, Qatar. https://doi.org/10.5339/nmejre.2016.2

Khattab, N. (2014). How and when do educational aspirations, expectations and achievement align? Sociological Research Online, 19(4), 7. http://dx.doi.org/10.5153/sro.3508

Khattab, N. (2015). Students' aspirations, expectations and school achievement: What really matters? British Educational Research Journal, 41(5), 731-748. http://dx.doi.org/10.1002/berj.3171

King, J. E. (2010). Gender equity in higher education: 2010. Washington, DC: American Council on Education.

Kirst, M. W. \& Venezia, A. (Eds.). (2004). From high school to college. San Francisco: Jossey-Bass.

Kleinjans, K. J. (2010). Family background and gender differences in educational expectations. Economics Letters, 107(2), 125-127. http://dx.doi.org/10.1016/j.econlet.2010.01.002

Lee, S. (2016). What motivates and engages students in the education process - An examination of Qatari students' mindset and attitudes toward going to school, learning, and future aspirations. Journal of Education and Learning, 5(3), 220. http://dx.doi.org/10.5539/jel.v5n3p220

Lowman, J. \& Elliott, M. (2010). A multilevel model of educational expectations of secondary school students in the United States. Social Psychology of Education, 13(1), 77-110. https://doi.org/10.1007/s11218-009-9099-x

McCarron, G. P. \& Inkelas, K. K. (2006). The gap between educational aspirations and attainment for first-generation college students and the role of parental involvement. Journal of College Student Development, 47(5), 534-549. http://dx.doi.org/10.1353/csd.2006.0059

McDaniel, A. (2009). Cross-national gender gaps in educational expectations: The influence of national-level gender ideology and educational systems. Comparative Education Review, 54(1), 27-50. http://dx.doi.org/10.1086/648060 
Miller, J. D. \& Solberg, V. S. (2012). The composition of the STEMM workforce: Rationale for differentiating STEMM professional and STEMM support careers. Peabody Journal of Education, 87(1), 6-15. http://dx.doi.org/10.1080/0161956x.2012.642232

Ou, S. R. \& Reynolds, A. J. (2008). Predictors of educational attainment in the Chicago longitudinal study. School Psychology Quarterly, 23(2), 199-229. http://dx.doi.org/10.1037/1045-3830.23.2.199

Paik, S. J. (2004). Korean and US families, schools, and learning. International Journal of Educational Research, 41(1), 71-90. http://dx.doi.org/10.1016/j.ijer.2005.04.006

Patall, E. A., Cooper, H. \& Robinson, J. C. (2008). Parent involvement in homework: A research synthesis. Review of Educational Research, 78(4), 1039-1101. http://dx.doi.org/10.3102/0034654308325185

Price, D. V. \& Tovar, E. (2014). Student engagement and institutional graduation rates: Identifying high-impact educational practices for community colleges. Community College Journal of Research and Practice, 38(9), 766-782. https://doi.org/10.1080/10668926.2012.719481

Pruett, P. S. (2015). Factors influencing the retention of developmental students in community colleges (Unpublished doctoral dissertation). Union University. Jackson Tennessee, USA.

Qatar General Secretariat for Development Planning (QGSDP). (2011). Qatar national development strategy 2011-2016 (NDS). http://www.gsdp.gov.qa/gsdp_vision/docs/NDS_EN.pdf

Reynolds, J. R. \& Burge, S. W. (2008). Educational expectations and the rise in women's post-secondary attainments. Social Science Research, 37(2), 485-499. http://dx.doi.org/10.1016/j.ssresearch.2007.09.002

Reynolds, J. R. \& Pemberton, J. (2001). Rising college expectations among youth in the United States: A comparison of the 1979 and 1997 NLSY. The Journal of Human Resources, 36(4),703-726. http://dx.doi.org/10.2307/3069639

Sadler, P. M., Sonnert, G., Hazari, Z. \& Tai, R. (2012). Stability and volatility of STEM career interest in high school: A gender study. Science Education, 96(3), 411-427. http://dx.doi.org/10.1002/sce.21007

Sammons, P. M, Toth, K. \& Sylva, K. (2016). Believing in better: How aspirations and academic self-concept shape young people's outcomes. The Sutton Trust and of the Education Endowment Foundation. http://www.suttontrust.com/wp-content/uploads/2016/06/EPPSE-final-Believing-in-Better.pdf

Schmitt-Wilson, S. \& Faas, C. (2016). Alignment of educational and occupational expectations influences on young adult educational attainment, income, and underemployment. Social Science Quarterly, 97(5), 1174-1188. http://dx.doi.org/10.1111/ssqu.12244

Schneider, M. \& Yin, L. M. (2012). Completion matters: The high cost of low community college graduation rates. AEI Education Outlook, 2, 1-10.

Scott, A. B. \& Mallinckrodt, B. (2005). Parent emotional support, science self-efficacy, and choice of science major in undergraduate women. The Career Development Quarterly, 53(3), 263-273. http://dx.doi.org/10.1002/j.2161-0045.2005.tb00995.x

Sosu, E. M. (2014). Predicting maternal aspirations for their children's education: The role of parental and child characteristics. International Journal of Educational Research, 67, 67-79. http://dx.doi.org/10.1016/j.ijer.2014.05.003

Stasz, C., Eide, E. R. \& Martorell, P. (2007). Post-secondary education in Qatar: Employer demand, student choice, and options for policy. Santa Monica, CA: RAND Education.

Supreme Education Council. (2012). Schools and schooling in Qatar 2011-2012. SEC: Doha, Qatar. http://www.sec.gov.qa/En/SECInstitutes/EvaluationInstitute/SEO/Pages/StatisticalReport.aspx

The Ministry of Education and Higher Education (2016). The education and training sector strategy (ETSS) 2011. http://www.edu.gov.qa/En/about/Documents/Stratgy2012E.pdf

The Social \& Economic Survey Research Institute (SESRI). (2012). Qatar education study 2012: Students' motivation and parental participation report. Doha, Qatar: Qatar University. http://hdl.handle.net/10576/4670

Trusty, J. (1998). Family influences on educational expectations of late adolescents. The Journal of Educational Research, 91(5), 260-271. https://doi.org/10.1080/00220679809597553 
Trusty, J. (2000). High educational expectations and low achievement: Stability of educational goals across adolescence. The Journal of Educational Research, 93(6), 356-365. http://dx.doi.org/10.1080/00220670009598730

Trusty, J. (2002). African American's educational expectations: Longitudinal causal models for women and men. Journal of Counseling and Development, 80(3), 332. http://dx.doi.org/10.1002/j.1556-6678.2002.tb00198.x

Trusty, J. \& Harris, M. B. C. (1999). Lost talent: Predictors of the stability of educational expectations across adolescence. Journal of Adolescent Research, 14(3), 359-382. http://dx.doi.org/10.1177/0743558499143005

Trusty, J., Plata, M. \& Salazar, C. F. (2003). Modeling Mexican Americans' educational expectations: Longitudinal effects of variables across adolescence. Journal of Adolescent Research, 18(2), 131-153. http://dx.doi.org/10.1177/0743558402250345

Turley, R. N. L., Santos, M. \& Ceja, C. (2007). Social origin and college opportunity expectations across cohorts. Social Science Research, 36(3), 1200-1218. http://dx.doi.org/10.1016/j.ssresearch.2006.09.004

Tyson, W., Lee, R., Borman, K. M. \& Hanson, M. A. (2007). Science, technology, engineering, and mathematics (STEM) pathways: High school science and math coursework and postsecondary degree attainment. Journal of Education for Students Placed at Risk, 12(3), 243-270. http://dx.doi.org/10.1080/10824660701601266

Vryonides, M. \& Gouvias, D. (2012). Parents' aspirations for their children's educational and occupational prospects in Greece: The role of social class. International Journal of Educational Research, 53, 319-329. http://dx.doi.org/10.1016/j.ijer.2012.04.005

Uwah, C. J., McMahon, H. G. \& Furlow, C. F. (2008). School belonging, educational aspirations, and academic self-efficacy among African American male high school students: Implications for school counselors. Professional School Counseling, 11(5), 296-305. DOI: 10.1177/2156759X0801100503

Wahl, K. H. \& Blackhurst, A. (2000). Factors affecting the occupational and educational aspirations of children and adolescents. Professional School Counseling, 3(5), 367-374.

Wang, D. B. (2004). Family background factors and mathematics success: A comparison of Chinese and US students. International Journal of Educational Research, 41(1), 40-54. http://dx.doi.org/10.1016/j.ijer.2005.04.013

Wells, R. S., Seifert, T. A. \& Saunders, D. B. (2013). Gender and realized educational expectations: The roles of social origins and significant others. Research in Higher Education, 54(6), 599-626. http://dx.doi.org/10.1007/s11162-013-9308-5

Wells, R. S., Seifert, T. A., Padgett, R. D., Park, S. \& Umbach, P. D. (2011). Why do more women than men want to earn a four-year degree? Exploring the effects of gender, social origin, and social capital on educational expectations. The Journal of Higher Education, 82(1), 1-32. http://dx.doi.org/10.1353/jhe.2011.0004

Wilder, S. (2014). Effects of parental involvement on academic achievement: A meta-synthesis. Educational Review, 66(3), 377-397. http://dx.doi.org/10.1080/00131911.2013.780009

Wood, D., Kaplan, R. \& McLoyd, V. C. (2007). Gender differences in the educational expectations of urban, low-income African American youth: The role of parents and the school. Journal of Youth and Adolescence, 36(4), 417-427. http://dx.doi.org/10.1007/s10964-007-9186-2 